Printed by: gcbme4@gmail.com. Printing is for personal, private use only. No part of this book may be reproduced or transmitted without publisher's prior permission. Violators will be prosecuted.

Advances in Business, Management and Entrepreneurship - Hurriyati et al. (Eds) C 2021 Taylor \& Francis Group, London, ISBN 978-0-367-67471-7

\title{
Citizen trust in local government: Explaining the role of village service
}

\author{
R. Ambarwati \& F.F. Lestariana \\ Universitas Muhammadiyah Sidoarjo, Sidoarjo, Indonesia
}

\begin{abstract}
Trust in local governments is needed in crises such as natural disasters, economic emergencies, or political un-rest. The purpose of this study was to measure citizen trust in government public services, particularly in village areas. The data used in this survey was collected through questionnaires distributed to rural communities that use government public services. Explanatory Factor Analysis was applied to analyze the data. The results of this study indicated that the quality of public services was the dominant factor. However, partisan involvement was a factor of concern in increasing citizen trust. The practical research is useful to increase trust in village government services as part of the supporting factors for the success of central government development programs.
\end{abstract}

\section{INTRODUCTION}

The current decline in the image of public institutions can cause degradation of public trust. Public trust in public institution is an absolute necessity since the purpose of the institution itself is to serve and meet the needs of the community both directly and indirectly (Bertot et al.. 2016), therefore building relationships and trust in the community is very important for public institutions. A good relationship between the community and the public institution result in confidence on the service process and that the institution is one of the right choices (Kim 2014), so that the desire to use services outside public institutions is smaller. Therefore, public trust is a critical to understand so that the agency can increase community trust and in turn will lead to trust in their organization (Danish, et al. 2013). Service performance is another critical problem that civil servants try to improve by doing excellent service based on what the community expects and desires (Taylor 2014). Improving public services is a longterm effort, to realize a real bureaucratic concept in which the public is primary right holder is not an easy task (Graham et al. 2015). Public service laws are enacted to strengthen, monitor, and provide direction, such as Law no. 25 of 2009 regarding Public Services. It aims to improve the delivery of public services by creating a mechanism to ensure public expectation and demands of the citizens are met.

Implicitly, bureaucratic trust is the primary function of government performance. The bureaucratic reform policies are aimed to increase citizens trust in one country and are equally suitable for other countries (Grimmelikhuijsen \& Knies 2017). Trust can be defined as relationships between two or more individuals, between individuals and organizations (such as companies or social service departments), or between several organizations" (Ma \& Wang 2014). Research in public administration discussed citizen attitudes on public sector, public trust, citizens' assessment on public institutions officials (Ramesh 2017). Some of them assessed the competence of public officials in carrying out designated assignments and affective evaluation of ethical and caring behavior or having the interests in service users (Griffin \& Halpin 2018). The trust in institutions requires employees to be competent, credible, and willing to act for the greater public interest. Public trust concerns the extent to which citizens have confidence in public institutions to operate in the best interests of society and their constituents (Ferry et al. 2018).

Regarding bureaucratic performance, a lack of trust relates to limited administrative authority delegation, excessive oversight, and excessive dependence on formal rules and procedures (Katoch et al. 2017). Besides, the low level of public trust undermines morale, retention, and recruitment of civil servants. Apart from evidence, policymakers concern with the status of trust in the public bureaucracy (Mourtada \& Salem 2015) as it often offers poor administrative performance and cause declining public satisfaction.

Public service plays an essential role in general welfare. The main problem for civil government services is the lack of perceptions of citizen trust. It needs the correct steps to increase citizen trust (Agyemang \& Ofei 2013). Several previous studies analyzed about the implementation of good governance. However, only very few focused on measuring citizen trust. The studies found that ethnic majority had more trust in public institutions than minority. Identity, language of administration, and lack of equal representation in the 
bureaucracy were also considerably determined the level of trust citizens had in public institutions.

Further, political patronage in service delivery has subverted the quality of public institutions and trust. Interestingly, citizens who support and being affiliated with the ruling party tend to have more trust in government. Police and village-level officers are least trusted, owing to endemic corruption (Ramesh 2017). The models reveal that the movement of power to select local leaders from the hands of upper-level government to residents erodes the influence of the so-called 'traditional authority orientation' among citizens, and enables them to assess trust level according to the competence of the government. Furthermore, elections cut back the trust-generating result of institutional tendency as voters. The voters are enfranchised within the 'input' method of the presidency, so accentuation 'outputs' less (Ma \& Wang 2014). Trust is correlated with both subjective (at the individual-level) and objective (at the national level) indicators of performance. The quality of institutions also matters as countries with lower levels of public sector corruption experience higher levels of trust in the civil service (Houston et al. 2016).

This study measures citizen trust in public services of the government, especially in the village. The measurement used several indicators, including Quality of service, Information and Knowledge, Partisans, and Promise of Politicians.

\section{METHODS}

This study measures citizens' trust in government public services village areas. The measurement used several indicators i.e. quality of service, information and knowledge, partisans, and promise politicians promise. This study was a survey that collected the data using questionnaires.

The unit of analysis was rural communities that used public services. The data was analyzed using Structural Equation Modeling. The population in this study was all villagers in the Sidoarjo District who used and had been involved in public services in the village administration, aged between 17-65 years. The minimum education level was high school or equivalent. The sampling method was probability sampling and the technique of determining the sample unit was simple random sampling. The sample size in this study was 185-200.

Data was collected by distributing questionnaires and direct interviews with respondents. The measurement of data used a Likert scale to measure attitudes, opinions, and perceptions of the respondents on the object. This research was conducted within three months period from January to March 2019.

In the data processing stage, researchers used SEM (Structural Equation Modelling). The results of data analysis were interpreted to find out dimensions that formed citizen trust. The recommendations in this study were the results of discussion and interpretation

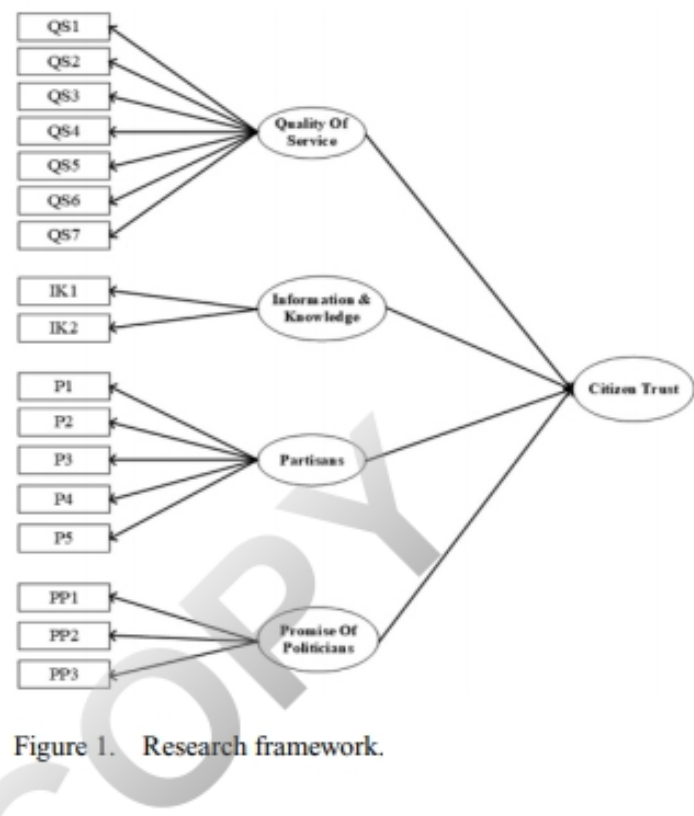

of data analysis processed by SEM. The researcher formulated the research framework as presented in Figure 1.

\section{RESULTS AND DISCUSSION}

The testing instrument was aimed to measure formative indicators of Citizen Trust. The outer weight significance value with T-statistics $>1.96$, it was obtained through a resampling (bootstrapping) procedure which meant construct validity and reliability was not required.

As shown as Table 1, Citizen Trust measurement used four indicators, namely: quality of service, information and knowledge, partisans, and promise of politicians. Quality of service indicator had an outer weight, which was the most dominant in forming Citizen Trust with a value of 0.401 significant with $\mathrm{CR}=$ 34.46. Quality of service showed that the government is responsive in terms of policymaking and promotes their ideology. It also indicates political parties continue the previous program when in power, public services are provided on time, the behavior of friendly public service providers, public service providers, can always solve problems, and the quality of public services is excellent. Awareness of the need for unique and satisfying public services has grown from the government before the reform era but has not been followed by implementing public service providers as expected (Houston et al. 2016). The village officials hold responsibilities to provide public services. Good or bad services offered to the community will depend on the quality and quantity, effectiveness, and efficiency (Ma \& Wang 2014). The population as the party being served will receive the service in various perceptions. 
Table 1. Path coefficients of citizen trust indicators.

\begin{tabular}{lll}
\hline & $\begin{array}{l}\text { Outer } \\
\text { weight }\end{array}$ & $\begin{array}{l}\text { Critical } \\
\text { ratio (CR) }\end{array}$ \\
\hline CT11 <- CT1 & 0,601 & 8,820 \\
CT12 <- CT1 & 0,698 & 12,232 \\
CT13 <- CT1 & 0,784 & 21,394 \\
CT14 <- CT1 & 0,827 & 32,371 \\
CT15 <- CT1 & 0,701 & 17,129 \\
CT16 <- CT1 & 0,646 & 14,739 \\
CT17 <- CT1 & 0,766 & 22,675 \\
CT21 <- CT2 & 0,878 & 32,214 \\
CT22 <- CT2 & 0,897 & 50,948 \\
CT31 <- CT3 & 0,802 & 25,907 \\
CT32 <- CT3 & 0,868 & 45,523 \\
CT33 <- CT3 & 0,804 & 14,574 \\
CT34 <- CT3 & 0,633 & 8,057 \\
CT35 - CT3 & 0,763 & 22,293 \\
CT41 <- CT4 & 0,901 & 30,989 \\
CT42 <- CT4 & 0,915 & 68,754 \\
CT43 <- CT4 & 0,775 & 20,726 \\
Quality of Service (CT1) -> CT & 0,401 & 34.46 \\
Information \& Knowledge (CT2) -> CT & 0,157 & 21.01 \\
Partisans (CT3) - CT & 0,324 & 14.70 \\
Promise of Politicians (CT4) -> CT & 0,232 & 16.74 \\
\hline & & \\
\hline
\end{tabular}

Source: Results of data processing from SmartPLS

The indicator of Information and Knowledge with outer weight value of 0.157 significant with $\mathrm{CR}=$ 21.01. This indicator explained how information about services can increase citizen satisfaction and confidence in good public service performance. This indicator was a less dominant factor in shaping Citizen Trust because it had the smallest value outer weight compared to other indicators. Ease of access to information and knowledge can increase citizen trust in the government (Ma \& Wang 2014). Communities need information about the government and legal services. The public will feel justice and security once it is fulfilled.

Indicator of Partisans with a value of 0.324 was significant with $\mathrm{CR}=14.70$. This indicator explained how partisan affiliation in government increased citizen trust, satisfaction with service quality, trust in government policies. Non-partisans also share the same beliefs with individuals, increased trust in nonpartisans through excellent performance. This indicator was also the dominant factor to form Citizen Trust because as it was the second largest value outer weight after the quality service indicator. The importance of community participation in the formulation of public policies in the region's public administration is the result of the collaboration of various actors, both government, society, experts, and social institutions (Graham et al. 2015).

The Politician Promise had an outer weight value at 0.232 significant with $\mathrm{CR}=16.74$. This indicator explained that honest public service provider, fair public service providers, promises made by politicians are fulfilled, and local politicians are more reliable than the national level. Trust in politics is inseparable from the political actors themselves. Here the existence of a political elite is one of the focus. The political elite is a small group of people who have a significant influence in making and implementing political decisions. The political elite, in this case, has a source of power that includes political power, and the existence of this political elite is little when compared to the population in a country (Hessami 2014).

\section{CONCLUSION}

This research focused on all government public service in village areas. From the result, it can be concluded that quality of service is a dominant factor that can increase citizen trust. The village officials should also foster good relationships with the partisans and increase the involvement of non-partisans in village development activities.

This research has an implication on public services in villages which function as the extension of central government.

It also expected that this research shed light not only on Citizen Trust to build excellent public service, but also on how to create good governance in local government

\section{ACKNOWLEDGEMENT}

The authors would like to thank Indonesia Directorate General of Higher Education and Universitas Muhammadiyah Sidoarjo for supporting the publication of this research.

\section{REFERENCES}

Agyemang, C.B. \& Ofei, S.B. 2013. Employee work engagement and organizational commitment: a comparative study of public sector organizations in Ghana. European Journal of Business and Innovation Research.

Bertot, J., Estevez, E. \& Janowski, T. 2016. Universal and contextualized public services: Digital public service innovation framework. Government Information Quarterly. https://doi.org/10.1016/j.giq.2016.05.004.

Danish, R.Q., Ramzan, S. \& Ahmad, F. 2013. Effect of perceived organizational support and work environment on organizational commitment; mediating role of self-monitoring. Advances in Economics and Business. https://doi.org/10.13189/AEB.2013.010402.

Ferry, L., Glennon, R. \& Murphy, P. 2018. Local government. In Public Service Accountability: Rekindling a Debate. https://doi.org/10.1007/978-3-319-93384-9_3.

Graham, M.W., Avery, E.J. \& Park, S. 2015. The role of social media in local government crisis communications. Public Relations Review. https://doi.org/10.1016/j.pubrev.2015. 02.001

Griffin, D. \& Halpin, E. 2018. Local government: A digital intermediary for the information age? Information Polity. https://doi.org/10.3233/ip-2002-0019 
Printed by: gcbme4@gmail.com. Printing is for personal, private use only. No part of this book may be reproduced or transmitted without publisher's prior permission. Violators will be prosecuted.

Grimmelikhuijsen, S. \& Knies, E. 2017. Validating a scale for citizen trust in government organizations. International Review of Administrative Sciences. https://doi.org/ $10.1177 / 0020852315585950$

Hessami, Z. 2014. Political corruption, public procurement, and budget composition: Theory and evidence from OECD countries. European Journal of Political Economy. https://doi.org/10.1016/j.ejpoleco.2014.02.005

Houston, D.J., Aitalieva, N.R., Morelock, A.L., \& Shults, C.A. 2016. Citizen Trust in Civil Servants: A CrossNational Examination. International Journal of Public Administration. https://doi.org/10.1080/01900692.2016. 1156696.

Katoch, D., Sharma, J.S., Banerjee, S., Biswas, R., Das, B., Goswami, D. \& Mukherjee, P. K. 2017. Government policies and initiatives for development of Ayurveda Journal of Ethnopharmacology. https://doi.org/10.1016/ j.jep.2016.08.018

Kim, H. 2014. Transformational Leadership, Organizational Clan Culture, Organizational Affective Commitment, and Organizational Citizenship Behavior: A Case of South Korea's Public Sector. Public Organization Review. https://doi.org/10.1007/s11115-013-0225-z

Ma, D. \& Wang, Z. 2014. Governance Innovations and Citizens' Trust in Local Government: Electoral Impacts in China's Townships. Japanese Journal of Political Science. https://doi.org/10.1017/s1468109914000152

Mourtada, R. \& Salem, F. 2015. Citizen Engagement and Public Services in the Arab World: The Potential of Social Media. SSRN. https://doi.org/10.2139/ssrn.2578993

Ramesh, R. 2017. Does Trust Matter? An Inquiry on Citizens Trust in Public Institutions of Sri Lanka. Millennial Asia. https://doi.org/10.1177/0976399617715820

Taylor, J. 2014. Public service motivation, relational job design, and job satisfaction in local government. Public Administration. https://doi.org/10.1111/j.1467-9299. 2012.02108. $\mathrm{x}$ 